City University of New York (CUNY)

CUNY Academic Works

\title{
The crime kaleidoscope: A cross-jurisdictional analysis of place features and crime in three urban environments
}

Jeremy D. Barnum

Rutgers University

Joel M. Caplan

Rutgers University

Leslie W. Kennedy

Rutgers University

Eric L. Piza

CUNY John Jay College

\section{How does access to this work benefit you? Let us know!}

More information about this work at: https://academicworks.cuny.edu/jj_pubs/181

Discover additional works at: https://academicworks.cuny.edu

This work is made publicly available by the City University of New York (CUNY).

Contact: AcademicWorks@cuny.edu 


\title{
The crime kaleidoscope: A cross-jurisdictional analysis of place features and crime in three urban environments
}

\author{
Jeremy D. Barnum ${ }^{a,}{ }^{*}$, Joel M. Caplan ${ }^{a}$, Leslie W. Kennedy ${ }^{a}$, Eric L. Piza ${ }^{b}$ \\ ${ }^{a}$ Rutgers Center on Public Security, Rutgers University School of Criminal Justice, Newark, NJ, USA \\ bohn Jay College of Criminal Justice, City University of New York, USA
}

\section{A R T I C L E I N F O}

\section{Article history:}

Received 25 May 2016

Received in revised form

17 October 2016

Accepted 22 December 2016

\section{Keywords:}

Crime pattern theory

Risk terrain modeling

Spatial influence

Robbery

\begin{abstract}
A B S T R A C T
Research identifies various place features (e.g., bars, schools, public transportation stops) that generate or attract crime. What is less clear is how the spatial influence of these place features compares across relatively similar environments, even for the same crime. In this study, risk terrain modeling (RTM), a geospatial crime forecasting and diagnostic tool, is utilized to identify place features that increase the risk of robbery and their particular spatial influence in Chicago, Illinois; Newark, New Jersey; and Kansas City, Missouri. The results show that the risk factors for robbery are similar between environments, but not necessarily identical. Further, some factors were riskier for robbery and affected their surrounding landscape in different ways that others. Consistent with crime pattern theory, the results suggest that the broader organization of the environmental backcloth affects how constituent place features relate to and influence crime. Implications are discussed with regard to research and practice.
\end{abstract}

(c) 2016 Elsevier Ltd. All rights reserved.

\section{Introduction}

Crime can happen anywhere, but some places are more likely to experience crime than others. Research has found that a majority of police demand originates from just a few places (e.g., Braga, Hureau, \& Papachristos, 2011; Braga, Papachristos, \& Hureau, 2010; Sherman, Gartin, \& Buerger, 1989; Weisburd, Groff, \& Yang, 2012). Places are "very small micro units of analysis," including specific addresses, groups of addresses, block faces, or street segments (Weisburd, 2008, p. 2). Crime concentrates at certain places because of their unique social and physical qualities, which creates context that invites and sustains legally problematic behavior (Eck \& Weisburd, 1995; Kennedy, Caplan, \& Piza, 2011).

Environmental criminological theories (Wortley \& Mazerolle, 2008) frame crime events within the context of the environmental backcloth (Brantingham \& Brantingham, 1993). Distributed through this backcloth are place features, such as bars, schools, or public transportation stops that generate and attract crime (e.g., Brantingham \& Brantingham, 1995). However, environments are highly complex, and though many of the same features exist within different environments, their overall form and function is distinct

\footnotetext{
* Corresponding author. School of Criminal Justice, Rutgers University - Newark, 123 Washington Street, Newark, NJ, 07102, USA.

E-mail address: jeremy.barnum@rutgers.edu (J.D. Barnum).
}

(Lynch, 1960). Kennedy (1983) refers to the kaleidoscopic organization of place features about the urban landscape resulting from variety of forces (i.e., historical, cultural political, and economic) that influences its past and ongoing development. Poon (2015) posits that environments have their own "spatial DNA." Given the relative organization of each jurisdiction's environmental backcloth, the spatial influence of constituent place features on crime may not necessarily generalize across environments, even for the similar types of crime.

This study compares the criminogenic spatial influence of place features in different urban environments. It is hypothesized that place features commonly assumed to correlate with crime may not have a static influence, even across similar types environments for similar types of crime. Risk terrain modeling (RTM), a geospatial crime forecasting and diagnostic tool (Caplan, Kennedy, \& Miller, 2011), is utilized to identify place features that increase the risk of robbery and their particular spatial influence in Chicago, Illinois; Newark, New Jersey; and Kansas City, Missouri. The results show that the significant risk factors for robbery were similar across environments, but not necessarily identical. In other words, just because a given place feature aggravated robbery in one jurisdiction does not necessarily mean it did so in another. Further, some factors were riskier for robbery and affected their surrounding landscape in different ways than others. Consistent with theories of environmental criminology, the results suggest that the broader 
organization of the environmental backcloth affects how constituent place features relate to and influence crime, which has implications for theories of crime and place and policy implications pertaining to the ways in which police should respond to problematic places throughout their jurisdiction to achieve crime prevention.

\section{Conceptual framework}

In the mid-20th century Shaw and McKay (1942) observed that juvenile delinquency was unevenly distributed throughout the environmental landscape of Chicago. Specifically, they demonstrated that delinquency was highly concentrated in areas surrounding the center of the city and gradually declined in areas moving radially outward towards the edges of the city in a fashion consistent with the concentric zone model develop by Burgess (1925). Further, they found that delinquency remained highly concentrated in these particular areas over time, regardless of the people who lived there. ${ }^{5}$ They attributed their findings to social disorganization caused by broader structural forces of communities such as poverty, residential mobility, and demographic heterogeneity.

Subsequent research had difficulty generalizing these particular spatial patterns of crime to other cities (Bursik, 1988). Following World War II there was a large-scale population movement; "Dirty industries left [the inner city] to be in the suburbs, or even other developing countries. Downtown living became a luxury, and former working class neighborhoods [were] invaded by professionals in the process of gentrification" (Andresen, 2014, p. 21). Ecological change was the norm and the concentric zone model used by Shaw and McKay to illustrate the distribution of crime in Chicago did not necessarily "fit" other cities. Indeed, alternative ecological models such as the sector model (Hoyt, 1939) and the multiple nuclei model (Harris \& Ullman, 1945) were developed to describe the ecological structure of other cities. Another limitation of this research was that "environments" from this perspective largely referred to community structural characteristics of an area, rather than the physical qualities of places (Kennedy, 1983). Yet, the built environment plays an important role in organizing human behavior and thereby providing ample opportunity for crime.

Crime pattern theory (Brantingham \& Brantingham, 2008) integrates notions of rational choice (Clarke \& Cornish, 1985) and routine activities (Cohen \& Felson, 1979) to describe this relationship. Essentially, crime is the product of decisions about offending and the distribution of offenders, targets, and guardians, each of which are shaped by the physical environmental landscape. Specifically, willing offenders are cued as they encounter viable opportunities for crime. Decision templates provide offenders with a mechanism for recognizing and discerning good from bad targets. Decisions that lead to successfully carrying out a criminal act reinforce the template; if unsuccessful, the template is revised to avoid such decisions in the future.

Crime opportunities arise within the context of the environmental backcloth (Brantingham \& Brantingham, 1993), which includes individuals' routine activities and the underlying networks of roads, buildings, and other infrastructure. Offenders and victims traverse the environment, engaging in their normal routines and traveling among their regular activity spaces. Crime occurs when offenders' encounter a target that fits their decision template. Such encounters are more likely to occur at places that facilitate the

\footnotetext{
5 "Areas" is utilized intentionally. The bulk of urban ecological research has focused on large areal units, such as census tracts or blocks. In contrast, more recent research has focused specifically on "places" as described by Weisburd (2008).
}

“overlapping lifestyles or spatio-temporal movement patterns" of offenders and targets (Brantingham \& Brantingham, 2008, p.87). Certain places do so more than others because they contain features that generate or attract crime (Brantingham \& Brantingham, 1995). Crime generators concentrate a large number of people, both potential offenders and victims, in specific locations at the same time. Crime is more likely at crime generators because of the large number of interactions that take place. Conversely, crime attractors specifically draw motivated offenders given well-known criminal opportunities.

Place features that generate and attract crime are distributed throughout the landscape along various paths, or the routes people take (e.g., roads, sidewalks, etc.) and edges, or distinct changes in the landscape (e.g., railways, changes in land use, neighborhood boundaries, etc.), which create nodes, or areas of intense activity (Brantingham \& Brantingham, 1984). The distribution of these features throughout each jurisdiction's environmental backcloth is unique as the result of various processes involving local policies and regulations with regard to zoning, infrastructure, and urban planning. Physical landscapes are constructed around natural terrains and molded around particular social, cultural, historical, and economic systems all of which influence their unique form and function and ongoing change and development. The combination of these forces ensures distinctiveness in the image of cities and the ways in which behavior within them unfolds (Lynch, 1960). Kennedy (1983, p.11) conceptualizes this through the analogy of a kaleidoscope (see Fig. 1). The kaleidoscope represents an environment (e.g., City A) and the shards of glass embody place features (e.g., bars, restaurants, public transportation stops) within that environment. The arrangement of place features encompasses an environment's form. Moving from one environment to the next (e.g., from City A to City B), or turning the kaleidoscope, alters the form of that environment. Central to the analogy is that the patterning of features varies between environments, but the parts and processes that create these patterns are the same. Thus, it is the particular combinations of features at places in different environments that must be identified to understand the distribution of behaviors and crime.

In sum, early ecological research demonstrated that crime is more likely in some areas of a city compared to others and suggested that there is value in considering what it is about those areas, beyond the individuals that exist there, that foster illegal behavior. However, this perspective primarily focused on community structural characteristics and largely neglected the influence of the physical features of environments on crime. Modern advances in data and technology have allowed researchers to demonstrate that crime is highly concentrated at very specific places throughout the geographic landscape. In this regard, several perspectives have emerged, falling under the broader realm of environmental criminology to provide a theoretical basis to this phenomenon. These perspectives discuss how physical place features throughout the environmental backcloth can generate or attract crime by structuring the everyday routines of individuals and creating good opportunities for offending. However, each jurisdiction has a unique backcloth and the particular ways in which certain features come together to create conditions for illegal behavior may not generalize, even for the same crime. Therefore, it is important to identify these patterns within the environmental backcloth of each jurisdiction to better understand the more localized spatial dynamics of crime.

\section{The study}

The purpose of this study is to examine the physical landscapes of different environments and their relative influence on crime. 


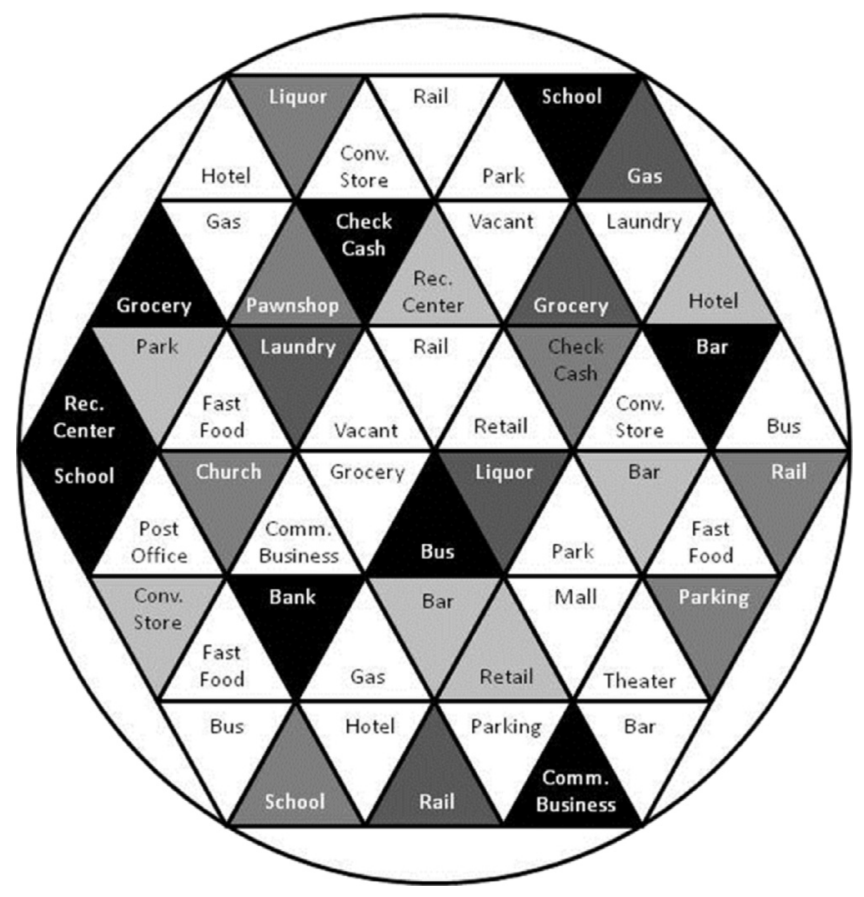

Fig. 1. (A) The kaleidoscope (i.e., environment) is composed of shards of glass (i.e., place features). The image (i.e., environmental form) that emerges is the result of the particular arrangement of glass shards. Turning the kaleidoscope (i.e., viewing another environment) alters this image. Crime concentrates at certain places within the environment, given the confluence of certain features that come together and create conditions that are conducive to offending.

More specifically, we utilize RTM to diagnose and compare criminogenic place features and their spatial influence on robbery in Chicago, Newark, and Kansas City. Consistent with environmental theories of crime it is assumed that certain place features will increase the risk for robbery. However, it is hypothesized that these features and their influence will vary across environments because they are uniquely patterned throughout each jurisdiction's environmental backcloth. Fig. 1 illustrates how place features are distributed throughout the environmental backcloth in a way that is conceptually similar to the shards of glass in a kaleidoscope. Crime concentrates at places within any given environment given the confluence of features that create conditions that are conducive to offending. However, observing another environment, or turning the kaleidoscope, alters these patterns and the resulting image. As environments change, so too do the distributions of people, offenders, targets, and guardians, and their routines, and the ideal opportunities for crime. Thus, it is important to examine the unique ways in which the environmental backcloth of different jurisdictions allows crime to emerge and persist.

\subsection{Risk terrain modeling}

The premise of RTM is that certain places have particular features that, when combined in prescribed ways, create context in which crime becomes more likely (Caplan et al., 2011, p. 365). The purpose of RTM is to diagnose place-based risk factors for crime and then identify where they are collocated to increase vulnerability to crime (Kennedy, Caplan, Piza, \& Buccine-Schraeder, 2015). The process of RTM involves a general series of steps beginning with the selection of an outcome event, a study setting, and time period. Then, all potentially risky place features are identified. The spatial influence of each feature is operationalized to a continuous surface of raster GRID cells in a geographic information system
(GIS). This produces a set of separate layers representing the spatial influence of each feature at every micro-level place (i.e., cell). Each risk layer is then empirically tested, weighted, and then combined with other statistically significant layers to create a composite risk terrain layer with each cell containing a value indicating the spatial influence of all risky place features throughout the entire geography.

\subsection{Data and study settings}

All data for this study were obtained as part of a larger study carried out in six cities across the United States (see Kennedy, Caplan, \& Piza, 2015). ${ }^{6}$ This presented a unique opportunity to investigate how place features influence crime across multiple environments at the same time in a consistent and standardized way. All data were sourced from the administrative records of police departments, purchased from Infogroup ${ }^{7}$, or collected online from publicly available databases as shapefiles or XY coordinates.

The study settings included Chicago, Illinois, Kansas City, Missouri, and Newark, New Jersey. Chicago has the largest population with nearly 2.7 million people over a total land area of approximately 227 square miles. Kansas City has the second largest population, with about 460,000 people, and the largest land area of about 315 square miles. Finally, Newark has both the smallest population and land area with approximately 277,000 residents living within just 24 square miles. However, the population density in Newark (11,458 persons per square mile) is similar to Chicago (11,841 persons per square mile), where Kansas City is much less densely populated (1459 persons per square mile).

\subsection{Outcome event}

Outcome events were calendar year 2012 robbery incidents (see Table 1). Robberies are often a substantial source of fear among urban residents (Wright \& Decker, 1997). Because over half involve a weapon, robberies have a high potential for serious harm (Federal Bureau of Investigation, 2012). The robbery rate in each study setting was three to six times higher than the national average (Federal Bureau of Investigation, 2012).

\subsection{Potential risk factors}

Various place features may aggravate or otherwise increase the risk for robbery. In total, 14 types of place features were selected in accordance with theory or existing empirical research to be tested for association with robbery in each study setting (see Table 1). Crime pattern theory describes how place features can act as crime generators by bringing together a large number of individuals for otherwise legitimate activity thereby increasing the potential for offenders to encounter ideal targets absent sufficient guardianship. Such features may include restaurants, retail shopping outlets, entertainment venues, commercial businesses, or public transportation stops (Brantingham \& Brantingham, 1995). Conversely, place features may function as crime attractors, specifically drawing in individuals seeking to exploit well-known criminal opportunities. Crime attractors may include bars, illicit markets, or insecure parking lots (Brantingham \& Brantingham, 1995). Generally speaking, classification of particular place features as crime generators or attractors is based on theoretical insights pertaining to the particular mechanisms that tie together those features and the specific crime problem at hand. Research in Chicago, for

\footnotetext{
${ }^{6}$ Funded by the National Institute of Justice (Award \#2012-IJ-CX-0038).

7 http://www.infogroup.com/.
} 
Table 1

Place feature counts and analysis parameters of risk terrain models for calendar year 2012 robbery incidents in Chicago, Kansas city, and Newark.

\begin{tabular}{llll}
\hline Variable & Chicago & Kansas City & Newark \\
\hline $\begin{array}{l}\text { Outcome Event } \\
\text { Robbery Incidents }\end{array}$ & 13,480 & 1638 & \\
Place Features & & & 2001 \\
Drug Arrests & 3334 & 2521 & \\
Parks & 10,581 & 24,037 & 4778 \\
Pawn Shops & 68 & 14 & 1350 \\
Bars & 1316 & 106 & 36 \\
Foreclosures & 15,305 & 311 & 192 \\
Gas Stations & 140 & 52 & 779 \\
Grocery Stores & 933 & 75 & 41 \\
Health Centers \& Gyms & 176 & 34 & 223 \\
Laundromats & 173 & 28 & 11 \\
Liquor Stores & 926 & 258 & 37 \\
Parking Stations & 218 & 23 & 87 \\
Schools & 1021 & 171 & 28 \\
Variety Stores & 124 & 34 & 724 \\
Bus Stops & 10,711 & 3790 & 922 \\
\hline
\end{tabular}

Model Parameters;

Cell Size/Block Length (in feet): Chicago (213/426); Kansas City (231/462); Newark (226/452).

Spatial Operationalization: Proximity and Density (Parks as Proximity; Drug Markets as Density).

Spatial Influence Extent/Analysis Increments: 3 Blocks/Half Blocks.

example, examined the spatial dynamics of drug dealing and found that incidents of marijuana, heroin, crack, and cocaine dealing each exhibited unique set of place-based risk factors with variable spatial influence (Barnum et al., 2016).

Existing research provides guidance on specific place features that facilitate robbery. For example, an important factor in a robber's decision to offend is the presence or availability of cash or other goods that can be quickly converted into cash (St. Jean, 2007; Wright \& Decker, 1997). Bernasco and Block (2011) examined numerous place features in Chicago that operate "small cash economies" where several individuals are likely to have cash on hand and found that several features, such as bars, liquor stores, grocery stores, gas stations, laundromats, liquor stores, pawnshops, and drug markets, among others, were related to robbery. Wright and Decker (1997) and St. Jean (2007), based on interviews with actual robbers, explain how these types of place features may attract robbers for additional reasons. For example, bars or liquor stores contain intoxicated patrons who are particularly vulnerable because they are not in a position to offer resistance (see also Groff, 2014; Roncek \& Bell, 1981; Roncek \& Maier, 1991). Pawnshops allow robbers to easily and quickly convert stolen goods into cash. Moreover, they could provide robbers with easy access to weapons to commit their offense. Drug markets may facilitate robbery because drug buyers and sellers, owing to their extralegal activities, are not likely to report their victimization.

Other important elements that inform the decision calculus of robbers relate to the accessibility and familiarity of places. In other words, robbers prefer places that are easy to get to and offer quick escape once they have committed their robbery (St. Jean, 2007; Wright \& Decker, 1997). This is likely to include places with features such as grocery stores, gas stations, laundromats, or other types of retail and commercial stores (Bernasco \& Block, 2011; Smith, Frazee, \& Davison, 2000). These types of businesses are likely to be located in popular areas that are frequented by a large number of people. They are convenient to travel to, owing to their connectedness to the rest of the city to enhance people traffic to increase business. They are likely to be located near parking locations or public transportation stops, other features that have been associated with crime, and specifically robbery (Bernasco \& Block,
2011; Groff \& Lockwood, 2014; Hart \& Miethe, 2014; Smith et al., 2000). These features also reduce the risk for detection because they have an ongoing rhythm of activity in which to easily blend in (St. Jean, 2007; Wright \& Decker, 1997).

Other features may create suitable conditions for robbery because they lack sufficient guardianship and thereby enhance the probability that a robber will successfully offend and remain anonymous. For example, Groff and McCord (2012) found that parks increased crimes in the surrounding areas, particularly when they had characteristics that reduced guardianship. Because they are unattended, foreclosures may also make robbery more likely. Spelman (1993) found that crime was higher near abandoned properties; a number of additional studies have documented a link specifically between foreclosures and violent crime (Baumer, Wolff, \& Arnio, 2012; Bess, 2008; Ellen, Lacoe, \& Sharygin, 2013). Several studies have found schools to be associated with higher levels of violent crime (Bernasco \& Block, 2009; Roncek \& Faggiani, 1985; Roncek \& Lobosco, 1983). Bernasco and Block (2009) suggest that schools provide good targets, but schools themselves may have high surveillance. However, this might not be the case in the surrounding areas, or after hours, where individuals may congregate unsupervised. Finally, health centers and gyms have received little attention in prior research, but may provide ideal targets for robbers. For example, these features may be attractive to robbers because they are often open around the clock and unstaffed (and consequently unguarded). People visit the gyms late at night to avoid crowds, often carrying only their wallet or a small electronic device such as an iPhone or iPod that can be easily grabbed as someone is coming or going to the gym and then converted into cash (e.g., see Caplan \& Kennedy, 2016, p. 99). Also, gyms are often located in highly trafficked areas owing to the need to be easily accessible for people on the way to and from work, school, or other daily activities.

\subsection{Model parameters and operationalization}

The Risk Terrain Modeling Diagnostics Utility (RTMDx; Caplan \& Kennedy, 2013) was used to create RTMs for calendar year 2012 robbery incidents and examine risky place features and their spatial influence in Chicago, Newark, and Kansas City. Besides the study setting boundaries, all other parameters were standardized across models to generate results that reflected variation in each jurisdiction's environmental backcloth rather than variations in model parameters or methods of testing.

First, "aggravating" models were specified, which identify positive spatial associations between potential risk factors and the outcome event, to determine risky place features ${ }^{8}$. Next, "cell sizes" and "block lengths," which served as the units of analysis for each model, were specified as one-half the average block length and the average block length in each study setting, respectively (Caplan, Kennedy, \& Piza, 2013). This is consistent with research suggesting the importance of examining the dynamics of crime at the micro unit of analysis (Weisburd, Bernasco, \& Bruinsma, 2008). Cell sizes and block lengths were determined via street centerline files ${ }^{9}$ (see Table 1).

The next set of parameters included "spatial operationalization," "maximum spatial influence," and "analysis increments" for each place feature tested. Spatial operationalization describes the

\footnotetext{
8 RTMDx can also create "protective" models, which search for negative spatial correlations between place features and crime. These features mitigate or otherwise decrease the risk of crime.

${ }^{9}$ Arbitrary nodes were removed to ensure breaks in street segments only occurred at true intersections.
} 
particular influence of each feature; that is, crime risk can be higher at places as a function of proximity to features or at places with a dense concentration or clustering of features. Theoretically, either, both, or neither operationalization of features could be true, given the particular environment (for a detailed discussion of operationalizing spatial influence, see Caplan, 2011). To determine when features generate the most risk, the spatial operationalization of most features was tested as both proximity and density ${ }^{10}$. There were two exceptions. First, parks were represented as polygon shapefiles, but RTMDx only accepts point features. Therefore, park polygons were converted to a representative grid of points and tested as proximity only. Second, drug arrest incidents ${ }^{11}$ represent a "fleeting" phenomenon that may reflect a standing quality of the environment when concentrated at places (Caplan et al., 2013) and tested as density only.

Finally, research suggests that the spatial influence of place features is geographically limited and decays with distance (e.g., Groff \& Lockwood, 2014). Therefore, the spatial influence of each feature was tested to a maximum extent of three blocks at halfblock analysis increments. In sum, the spatial influence of each place feature was tested at one-half block; one block; one-and-onehalf a block; two blocks; two-and-one-half blocks, and three blocks, as a function of proximity and density, respectively.

\subsection{Statistical analysis}

The statistics of RTMDx are only briefly described here (for a detailed discussion, see Heffner, 2013, p. 35). RTMDx begins by building an elastic net penalized regression model assuming a Poisson distribution of events. Cross-validation is used to reduce the initial set of variables. ${ }^{12}$ RTMDx continues by building additional models, one assuming a Poisson distribution and the other a negative binomial distribution. The Bayesian Information Criteria (BIC) is measured for a null model and then again as each new variable is added. RTMDx continues in this iterative fashion until the addition or removal of a new variable does not allow the model to surpass the BIC score of the previous candidate model. RTMDx finishes by choosing the model with the lowest BIC score between the two distributions. Coefficients for the remaining variables (i.e., risk factors) are rescaled between the minimum and maximum risk values to produce relative risk values (RRV), ${ }^{13}$ weighting each factor relative to one another. Relative risk scores (RRS) are computed for each cell within the study setting.

\section{Results}

Table 2 presents the risk factors for robbery in each study setting. For each risk factor, the models identified the optimal spatial operationalization, the maximum spatial influence, and a RRV. Of the 14 types of place features tested, 12 were risk factors for robbery in Chicago; 8 in Kansas City; and 10 in Newark. RRVs ranged from 1.25 to 4.60 in Chicago, from 1.57 to 8.69 in Kansas City, and from 1.46 to 9.61 in Newark. Gas stations were the riskiest

\footnotetext{
${ }^{10}$ RTMDx measures proximity using Euclidean (i.e., straight-line) distance. Kernel density estimation (KDE) is used to measure density.

${ }^{11}$ Following previous studies, drug arrest incidents are utilized to represent drug markets (e.g., see Eck, 1995; Rengert, Ratcliffe, \& Chakravorty, 2005; Weisburd \& Green, 1995)

12 Spatial autocorrelation can be problematic to the extent that when present, significance values may be affected and Type I errors are more likely. However, RTMDx employ cross-validation, which deemphasizes significance testing for variable selection (see Heffner, 2013: 38).

${ }^{13}$ Relative risk values are calculated by exponentiating risk factor coefficients provided by the risk terrain model.
}

Table 2

Risk terrain model results for calendar year 2012 robbery incidents in Chicago, Kansas city, and Newark.

\begin{tabular}{|c|c|c|c|c|c|c|}
\hline \multirow[t]{2}{*}{ Risk factor } & \multicolumn{2}{|l|}{ Chicago } & \multicolumn{2}{|c|}{ Kansas City } & \multicolumn{2}{|l|}{ Newark } \\
\hline & $\mathrm{O} / \mathrm{SI}$ & RRV & $\mathrm{O} / \mathrm{SI}$ & RRV & $\mathrm{O} / \mathrm{SI}$ & RRV \\
\hline Foreclosures & $\mathrm{P} / 852$ & 4.51 & $\mathrm{P} / 1386$ & 1.68 & $\mathrm{P} / 1356$ & 9.61 \\
\hline Gas Stations & $\mathrm{P} / 213$ & 4.60 & $\mathrm{D} / 462$ & 2.11 & $\mathrm{P} / 226$ & 2.65 \\
\hline Grocery Stores & $\mathrm{P} / 1065$ & 1.57 & $\mathrm{P} / 1386$ & 1.73 & $\mathrm{D} / 1356$ & 1.47 \\
\hline Health Centers \& Gyms & - & - & - & - & - & - \\
\hline Laundromats & $\mathrm{P} / 213$ & 2.27 & - & - & $\mathrm{P} / 226$ & 2.89 \\
\hline Parking Stations & $\mathrm{P} / 213$ & 1.96 & - & - & $\mathrm{P} / 904$ & 1.53 \\
\hline Variety Stores & $\mathrm{P} / 1278$ & 1.25 & $\mathrm{D} / 1386$ & 1.64 & - & - \\
\hline Bus Stops & $\mathrm{D} / 426$ & 2.55 & $\mathrm{D} / 1155$ & 5.38 & $\mathrm{P} / 226$ & 3.68 \\
\hline Bars & $\mathrm{P} / 213$ & 1.83 & - & - & $\mathrm{P} / 678$ & 1.46 \\
\hline Drug Markets & $\mathrm{D} / 1065$ & 2.36 & $\mathrm{D} / 231$ & 8.69 & $\mathrm{D} / 226$ & 2.39 \\
\hline Schools & $\mathrm{P} / 1278$ & 1.39 & - & - & $\mathrm{P} / 1356$ & 1.57 \\
\hline Parks & - & - & $\mathrm{P} / 1386$ & 1.57 & - & - \\
\hline Liquor Stores & $\mathrm{P} / 213$ & 2.97 & $\mathrm{P} / 1386$ & 2.19 & $\mathrm{P} / 1356$ & 1.50 \\
\hline Pawn Shops & $\mathrm{P} / 1278$ & 1.29 & - & - & - & - \\
\hline
\end{tabular}

Note: O: Operationalization ( $\mathrm{P}=$ Proximity or $\mathrm{D}=$ Density); SI: Spatial Influence (in feet) RRV: Relative Risk Value.

factor in Chicago. Places located within 213 feet (i.e., one-half a block) of a gas station were at 4.60 more risky for robbery compared to places absent the spatial influence of any risk factors. In Kansas City, the riskiest factor was drug markets and places where drug arrest incidents clustered within a 231-foot (i.e., one-half block) bandwidth were 8.69 times more risky for robbery compared to places absent any risk factors' influence. Foreclosures were the riskiest feature in Newark and places within 1356 feet (i.e., three blocks) of them were 9.61 as risky for robbery compared to places where no risk factors' influence was present.

Six features, including foreclosures, gas stations, grocery stores, bus stops, drug markets, and liquor stores were risk factors for robbery in all three study settings. This is largely consistent with findings reported by other studies (e.g., Bernasco \& Block, 2011; Hart \& Miethe, 2014; Smith et al., 2000; Spelman, 1993; St. Jean, 2007; Wright \& Decker, 1997). Some commonly identified correlates of robbery (as reported in aforementioned studies), however, were not risk factors in one or more study settings despite theoretical expectations or extant research suggesting they would have been. For example, parks were not risk factors for robbery in Chicago; laundromats, parking stations, bars, schools, and pawn shops were not risk factors in Kansas City; and variety stores, parks, and pawn shops were not risk factors in Newark. Health centers and gyms were not risk factors for robbery in any study setting.

Variations were observed in risk factors' spatial influences, specifically, their operationalizations, extents of influence, and weights of influence. With regard to operationalization, risk could be higher for robbery near features or at places where features clustered. Although foreclosures, gas stations, grocery stores, bus stops, and liquor stores were risk factors for robbery in all three study settings, only foreclosures and liquor stores shared the same operationalization. In all three study settings, risk was higher near foreclosures and liquor stores. Operationalizations varied for gas stations, grocery stores, and bus stops. For example, risk was also higher near gas stations in Chicago and Newark, and near grocery stores in Chicago and Kansas City. On the hand, risk was higher at places where gas stations clustered in Kansas City and at places where grocery stores clustered in Newark. Similarly, risk was higher at places where bus stops clustered in Chicago and Kansas City, but near bus stops in Newark. Drug markets was tested only as a function of density and was therefore operationalized as such in all three study settings.

The spatial influence of each feature was tested to a maximum extent of 3 blocks in half-block increments and the results show 
that the risk factors for robbery affected a different range of space across the three study settings. For example, although the spatial influence of liquor stores extended to just half a block in Chicago, it reached a full three blocks in Kansas City and Newark. Likewise, the spatial influence of drug markets in Chicago extended 2.5 blocks, but was limited to just half a block in Kansas City and Newark. Such variations could be observed for other risk factors between study settings, such as parking stations, bus stops, and bars. However, other risk factors, such as foreclosures, gas stations, grocery stores, Laundromats, variety stores, and schools, had similar extents of spatial influence.

Finally, some risk factors aggravated robbery more in certain study settings compared to others. This was measured as a function of each risk factors' RRV, essentially weights of influence. This was most salient for foreclosures, which were much riskier for robbery in Newark $(\mathrm{RRV}=9.61)$ than Chicago $(\mathrm{RRV}=4.51)$ or Kansas City $(\mathrm{RRV}=1.68)$. Moreover, gas stations generated over twice as much risk for robbery in Kansas City (RRV $=2.11$ ) and Newark $(\mathrm{RRV}=2.65)$, but nearly five times as much risk in Chicago $(\mathrm{RRV}=4.60)$. Drug markets were nearly nine times as risky for robbery in Kansas City ( $R R V=8.69$ ), but just over twice as risky in Chicago (RRV $=2.36$ ) and Newark (RRV = 2.39). Finally, bus stops were over twice as risky for robbery in Chicago ( $R R V=2.55$ ), over three times as risky in Newark (RRV $=3.68)$, and over five times as risky in Kansas City (RRV $=5.38$ ). Although the same risk factors were oftentimes more problematic in one setting compared to another, some consistencies emerged. For example, though significant aggravators for robbery, grocery stores, parking stations, bars, and schools were generally less problematic than other place features.

\section{Discussion}

RTM, a geospatial crime forecasting and diagnostic method, was utilized to identify risk factors for robbery and their spatial influence for comparison in Chicago, Newark, and Kansas City. The goal was to examine the physical landscape of different urban environments and their relative influence on crime. As environmental theories of crime would suggest, it was assumed that certain place features would increase the risk for robbery. However, it was hypothesized that these features and their particular influence on robbery would vary from one environment to the next given their unique patterning throughout each jurisdiction's environmental backcloth. Upon peering through each environment's crime risk kaleidoscope, a number of interesting findings emerged. First, each study setting had a unique set of risk factors for robbery. A second important finding was that the risk factors were oftentimes more problematic in some study settings as compared to others. Third, the spatial influence of risk factors oftentimes varied across study settings. In other words, risk was higher near features in some settings and at places where features clustered in other settings. Moreover, while the spatial influence of certain features extended several blocks in some settings it was relatively limited in others. Collectively, these findings suggest a unique set of underlying spatial dynamics that influence the emergence and persistence of robbery at places within each jurisdiction. Crime pattern theory (Brantingham \& Brantingham, 2008) suggests that these divergent spatial dynamics are the product of nuances in the physical aspects of each jurisdiction's environmental backcloth. As human creations and artifacts of more localized social, cultural, legal and economic processes, built environments are unique in their forms and functions. The ways in which physical landscapes shape opportunities for crime is not necessarily the same from one environment to the next.

This is reflected by differences in risk factors for robbery and their spatial influence across jurisdictions. Although it is not possible to speculate about all the variations observed in the findings, more broad theoretical considerations are warranted. For example, risk was higher near features in some jurisdictions but higher at places where the same types of features clustered in other jurisdictions. One possible explanation is that risk as a result of proximity to features may be reflective of the feature's crime attracting properties (Brantingham \& Brantingham, 1995). In other words, proximity to gas stations in Chicago and Newark could suggest that in these jurisdictions, gas stations have specific qualities that make robbery more likely nearby, such as being open late, providing a place for people to hang out (if there is a convenience store that sells cheap food and drink), and drawing a regular supply of customers who have cash on hand that make good targets. Conversely, risk at places due to the clustering of features may be more reflective of the feature's crime generating properties (Brantingham \& Brantingham, 1995). Perhaps in a large, relatively dispersed jurisdiction such as Kansas City, many gas stations are otherwise isolated in low traffic areas so proximity to just any gas station is not very risky. However, places where gas stations are clustered may be high activity nodes whereby both offenders and targets are concentrated and interact more frequently to increase the chances that good opportunities for crime will arise.

The distribution of place features along certain paths and relative to various types of edges may help to explain differences in extents of spatial influence too (Brantingham \& Brantingham, 1993). For example, paths consist of the underlying network of roads, sidewalks, or other routes of travel. Place features commonly located along more complex path networks may allow for a greater extent of influence as these networks have a greater capacity to support the everyday travel of offenders and victims in nearby areas. Conversely, robbery is more likely to happen at or very close to features that are located on a single, isolated road (e.g., see Beavon, Brantingham, \& Brantingham, 1994; Davies \& Johnson, 2015). Edges, or physical and perceptual barriers in the environment, could also play an important role in shaping the extent of influence of risk factors. For example, features near strong and clear edges are likely to host crimes within a very small area compared to features near "fuzzy" edges, which disperse crime over a large area (Brantingham, Brantingham, Vajihollahi, \& Wuschke, 2009). Additional research is required to directly incorporate path networks and the various edges throughout the environment backcloth to better understand how these elements work in conjunction to shape the influence of the physical landscape on crime.

Another important consideration is that the spatial arrangement of place features relative to one another throughout the environment may affect how they collocate and interact or work together to generate robbery risk. When certain features converge at places it creates a dynamic that is conducive to illegal behavior. Certain features, such as drug markets, may increase the risk for robbery because they operate primarily in cash and lack a formal third party to resolve disputes among competing dealers and their customers. Thus, robbery is primarily the result of participants in the drug market targeting one another. However, when collocated with or nearby other features, such as gas stations or public transportation stops, the criminogenic mechanisms may be enhanced because the latter features draw a larger number of people into the area, enabling a new set of suitable victims. For example, drug users may begin to target people who do not participate in the drug markets for their cash or valuables to purchase drugs. Thus, place features may increase robbery risk in their own right, but may become exponentially riskier when located near other features with criminogenic qualities. Indeed, features themselves may only become risky as a result of such co-effects. This study did not explicitly test the interaction effects between the risk factors to examine how the 
influence of certain features shapes that of other nearby features, but this is an important avenue for future inquiry.

At the same time, the distribution of place features throughout an environment may explain why certain features are not risky at all. Some place features typically associated with robbery may be located near "protective" features that undermine crime potential through enhanced guardianship (Clarke \& Eck, 2005). For example, studies have found that vacant lot cleaning and greening reduces crime and fear of crime (Branas, Cheney, MacDonald, Tam, Jackson, \& Ten Have, 2011; Garvin, Cannuscio, \& Branas, 2012). As a result, clean and green vacant lots might function as a crime mitigator by increasing the levels of residents' activities in the community. Another study found that levels of violence were lower in areas with more churches per capita (Lee, 2006), suggesting that churches may be another place feature with high levels of guardianship that may negate the aggravating mechanisms of nearby features (see also Eck \& Weisburd, 1995). Additional research is necessary to examine whether certain features do indeed provide a protective effect against crime, and moreover, how protective features interact with nearby risk factors.

These findings should be interpreted cautiously in light of a number of important limitations. First, and as with any study, these findings are directly tied to the quality of the data utilized in the analyses. With regard to the outcome event, this study utilized police recorded incidents of robbery. Although prior studies have utilized robbery incident data (e.g., Braga et al., 2011), they could be limited due to individuals' failing to report crimes or police decisions not to record crimes. Another issue was that it was not possible to make potentially relevant distinctions in the outcome event. For example, it is possible that the different findings would have emerged by distinguishing street and commercial robbery. Data quality is an equally important issue for the independent variables, or in this case potential risk factors for robbery, because improper classification or missing data can lead to model misspecification. Most place feature data utilized in this study were purchased from Infogroup. However, some place feature data were obtained from police departments or from open data portals. This could have introduced inconsistencies across jurisdictions. Although the place feature data utilized in the study were inspected for accuracy and completeness, it was not possible to visit the location of every place feature in each jurisdiction for true verification.

A second limitation was that the analyses here were exclusively concerned with the effects of place features on crime. Although place features do influence crime, it is likely that other variables are relevant, such as the broader community structural forces of poverty, population heterogeneity, neighborhood instability, and collective efficacy (Sampson \& Groves, 1989; Sampson, Morenoff, \& Gannon-Rowley, 2002). This is an important limitation, but it is worthwhile to note that a number of studies have examined the effects of place features on crime while controlling for community structure. For example, Groff and Lockwood (2014) controlled for population size and heterogeneity, disadvantage, and neighborhood stability and found that certain features, such as bars and public transportation stops, remain important predictors of violent crime. In another study Drawve, Thomas, and Walker (2016) utilized RTM to identify risk factors for violent crime and then created an aggregate neighborhood risk of crime measure (ANROC). They found that the ANROC measure was a significant and important predictor of violent crime, even when controlling for concentrated disadvantage and neighborhood stability. These studies demonstrate that place features can play an important role in crime, above and beyond community structure. However, it is likely that both environmental and social variables work together in complex ways to produce illegal behavior. For example, a recent study by Piza,
Feng, Kennedy, and Caplan (2016) found that the spatial influence of risk factors for motor vehicle theft and motor vehicle recovery varied across different neighborhood contexts. More specifically, they determined that certain place features increased the risk of motor vehicle theft and recovery, but that the criminogenic influence of these factors was either heightened or mitigated by certain neighborhood dynamics. They concluded that theories of environmental criminology and social disorganization are complementary perspectives. Although these studies add to the validity of the current study, future research that examines differences in risk factors for crime and their spatial influence should seek to incorporate community structure, as well as other possible sources of variation (e.g., policing intensity).

That this study did not include a temporal component was a third limitation because research has shown that risk factors' spatial influences can vary greatly across time periods (IrvinErickson, 2014). Finally, risk factors for robbery were compared across urban environments. It is less clear if similar findings would hold in smaller, more homogenous, suburban and rural settings. Future work that overcomes these limitations would greatly enhance the validity of the current findings and provide a better understanding of the kaleidoscope of risky places for crime.

Keeping in mind these limitations, this study has important policy implications. For example high crime places, also referred to as "hot spots" given their relatively high density of crime relative to other places throughout the broader jurisdiction (Sherman, 1995), provide an important avenue for crime prevention. It is welldocumented in the criminal justice literature that police operate more efficiently and effectively when focusing their resources and efforts on high crime places (Braga, Papachristos, \& Hureau, 2012). However, whereas hot spots inform police about places that are exposed to crime, they do less to describe the particular qualities of the places that make them vulnerable to crime (Kennedy et al., 2015). The methods utilized in this study can be incorporated into regular police practice to provide guidance about what exactly police should focus on at high crime places (see also Kennedy et al., 2011). This is particularly important given the current finding that the characteristics of high crime places depend upon the jurisdiction under consideration.

Police agencies can view specific crime problems through their own crime risk kaleidoscope to better understand and diagnose local crime vulnerabilities with appropriately customized interventions. This may include deploying common police tactics that have been found to be effective in addressing high crime places, such as directed patrol (Koper, Taylor, \& Woods, 2013; Rosenfeld, Deckard, \& Blackburn, 2014; Sherman \& Weisburd, 1995) or foot patrol (Novak, Fox, Carr, \& Spade, 2016; Piza \& O'Hara, 2014; Ratcliffe, Taniguchi, \& Wood, 2011), but with an even more refined focus on the risk factors that are present. For example, while on patrol, officers may direct their attention towards specific risk factors, whether that includes reporting unsecured vacant properties to other municipal agencies, approaching people at public transportation stops to educate them of recent crime problems and good ways to stay safe, or increasing their visibility and presence around bars. What is important is police can identify and prioritize actual crime vulnerabilities.

Tactics like directed patrol and foot patrol are important crime prevention measures, but more holistic long-term strategies, such as problem-oriented policing (Goldstein, 1990) or situational crime prevention (Clarke, 1980), are likely to be the most effective to this end (Skogan \& Frydl, 2004). The ultimate goal of any place-based police strategy is to fundamentally change the characters of places that are problematic (Braga \& Clarke, 2014). RTM can provide an empirical basis to problem assessments and inform the development of tailored interventions to address the localized conditions 
that affect crime (see Caplan \& Kennedy, 2016). For example, Kennedy, Caplan, and Piza (2015) examined the crime prevention value of various police activities that were specifically designed to mitigate or eliminate the criminogenic spatial influence of crime risk factors in multiple jurisdictions across the United States. They found that by employing risk reduction initiatives, measurable reductions in crime could be achieved. In one study setting, robbery was reduced by $42 \%$ in target areas relative to control areas. By addressing the environments that foster opportunities for crime, it is more likely that any crime prevention gains can be sustained over time.

\section{Funding}

This research was supported in part by a grant from the National Institute of Justice (2012-IJ-CX-0038). The views presented are those of the authors and do not necessarily represent the position of the National Institute of Justice.

\section{References}

Andresen, M. A. (2014). Environmental criminology: Evolution, theory, and practice. New York, NY: Routledge.

Baumer, E. P., Wolff, K. T., \& Arnio, A. N. (2012). A multicity neighborhood analysis of foreclosure and crime. Social Science Quarterly, 93, 577-601.

Barnum, Jeremy D., Campbell, Walter L., Trocchio, Sarah, Caplan, Joel M., \& Kennedy, Leslie W. (May 23 2016). Examining the Environmental Characteristics of Drug Dealing Locations. Crime \& Delinquency, Sage Journals.

Beavon, D. J. K., Brantingham, P. L., \& Brantingham, P. J. (1994). The influence of street networks on the patterning of property offenses. Crime Prevention Studies, 2, 115-148.

Bernasco, W., \& Block, R. (2009). Where offenders choose to attack: A discrete choice model of robberies in Chicago. Criminology, 47, 93-130.

Bernasco, W., \& Block, R. (2011). Robberies in Chicago: A block-level analysis of the influence of crime generators, crime attractors, and offender anchor points. Journal of Research in Crime and Delinquency, 48, 33-57.

Bess, M. (2008). Assessing the impact of home foreclosures in Charlotte neighborhoods. Geography and Public Safety. A Quarterly Bulletin of Applied Geography for the Study of Crime and Public Safety, 1(3), 2-4.

Braga, A. A., \& Clarke, R. V. (2014). Explaining high-risk concentrations of crime in the city: Social disorganization, crime opportunities, and important next steps. Journal of Research in Crime and Delinquency, 51(4), 480-498.

Braga, A. A., Hureau, D. M., \& Papachristos, A. V. (2011). The relevance of micro places to citywide robbery trends: A longitudinal analysis of robbery incidents at street corners and block faces in Boston. Journal of Research in Crime and Delinquency, 48(1), 7-32.

Braga, A. A., Papachristos, A. V., \& Hureau, D. M. (2010). The concentration and stability of gun violence at micro places in Boston, 1980-2008. Journal of Quantitative Criminology, 26(1), 33-53.

Braga, A., Papachristos, A., \& Hureau, D. (2012). Hot spots policing effects on crime. Campbell Systematic Reviews, 8, 1-96.

Branas, C. C., Cheney, R. A., MacDonald, J. M., Tam, V. W., Jackson, T. D., Have, T., et al. (2011). A difference-in-differences analysis of health, safety, and greening vacant urban space. American Journal of Epidemiology, 174(11), 1296-1306.

Brantingham, P., \& Brantingham, P. (1984). Patterns in crime. New York, NY: MacMillin Publishing Company.

Brantingham, P. L., \& Brantingham, P. J. (1993). Nodes, paths and edges: Considerations on the complexity of crime and the physical environment. Journal of Environmental Psychology, 13(1), 3-28.

Brantingham, P., \& Brantingham, P. (1995). Criminality of place. European Journal on Criminal Policy and Research, 3, 5-26.

Brantingham, P., \& Brantingham, P. (2008). Crime pattern theory. In R. Wortley, \& L. Mazerolle (Eds.), Environmental criminology and crime analysis. New York, NY: Routledge.

Brantingham, P. L., Brantingham, P. J., Vajihollahi, M., \& Wuschke, K. (2009). Crime analysis at multiple scales of aggregation: A topological approach. In D. Weisburd, W. Bernasco, \& G. J. N. Bruinsma (Eds.), Putting crime in its Place: Units of analysis in geographic criminology. New York: NY: Springer.

Burgess, E. W. 1984(1925, 1967). The growth of the city: An introduction to a research project. In R. Park, \& E. Burgess (Eds.), The city: Suggestions for investigation of human behavior in the urban environment, 1984(1925, 1967). Chicago, IL: University of Chicago Press.

Bursik, R. J. (1988). Social disorganization and theories of crime and delinquency: Problems and prospects. Criminology, 26(4), 519-552.

Caplan, J. M. (2011). Mapping the spatial influence of crime correlates: A comparison of operationalization schemes and implications for crime analysis and criminal justice practice. Cityscape, 13, 57-83.

Caplan, J. M., \& Kennedy, L. W. (2013). Risk terrain modeling diagnostics utility
(Version 1.0). Newark, NJ: Rutgers Center on Public Security.

Caplan, J. M., \& Kennedy, L. W. (2016). Risk terrain modeling: Crime prediction and risk reduction. Oakland, CA: University of California Press.

Caplan, J. M., Kennedy, L. W., \& Miller, J. (2011). Risk terrain modeling: Brokering criminological theory and GIS methods for crime forecasting. Justice Quarterly, 28, 360-381.

Caplan, J. M., Kennedy, L. W., \& Piza, E. L. (2013). Risk terrain modeling diagnostics utility user manual (Version 1.0). Newark, NJ: Rutgers Center on Public Security.

Clarke, R. V. (1980). Situational crime prevention: Theory and practice. British Journal of Criminology, 20, 136-147.

Clarke, R. V., \& Cornish, D. B. (1985). Modeling offenders' decisions: A framework for research and policy. Crime and Justice, 6, 147-185.

Clarke, R. V., \& Eck, J. E. (2005). Crime analysis for problem solvers in 60 small steps Washington, D.C.: U.S. Department of Justice, Office of Community Oriented Policing Services.

Cohen, L. E., \& Felson, M. (1979). Social change and crime rate trends: A routine activity approach. American sociological review, 44, 588-608.

Davies, T., \& Johnson, S. D. (2015). Examining the relationship between road structure and burglary risk via quantitative network analysis. Journal of Quantitative Criminology, 31(3), 481-507.

Drawve, G., Thomas, S. A., \& Walker, J. T. (2016). Bringing the physical environment back into neighborhood research: The utility of RTM for developing an aggregate neighborhood risk of crime measure. Journal of Criminal Justice, 44, 21-29.

Eck, J. E. (1995). A general model of the geography of illicit retail marketplaces. In J. E. Eck, \& D. Weisburd (Eds.), Crime and place: Crime prevention studies (Vol. 4, pp. 67-95). Monsey, NY: Criminal Justice Press.

Eck, J. E., \& Weisburd, D. (1995). Crime places in crime theory. Crime and Place, Crime Prevention Studies, 4(1), 1-33.

Ellen, I. G., Lacoe, J., \& Sharygin, C. A. (2013). Do foreclosures cause crime? Journal of Urban Economics, 74, 59-70.

Federal Bureau of Investigation. (2012). Crime in the United States. Washington, DC: Department of Justice.

Garvin, E., Cannuscio, C., \& Branas, C. (2012). Greening vacant lots to reduce violent crime: A randomised controlled trial. Injury Prevention, 19(3), 198-203.

Goldstein, H. (1990). Problem-oriented policing. Philadelphia, PA: Temple University Press.

Groff, E. R. (2014). Quantifying the exposure of street segments to drinking places nearby. Journal of Quantitative Criminology, 30, 527-548.

Groff, E. R., \& Lockwood, B. (2014). Criminogenic facilities and crime across street segments in Philadelphia: Uncovering evidence about the spatial extent of facility influence. Journal of Research in Crime and Delinquency, 51, 277-314.

Groff, E. R., \& McCord, E. S. (2012). The role of neighborhood parks as crime generators. Security Journal, 25(1), 1-24.

Harris, C. D., \& Ullman, E. L. (1945). The nature of cities. The Annals of the American Academy of Political and Social Science, 242, 7-17.

Hart, T. C., \& Miethe, T. D. (2014). Street robbery and public bus stops: A case study of activity nodes and situational risk. Security Journal, 27, 180-193.

Heffner, J. (2013). Statistics of the RTMDx utility. In J. M. Caplan, L. W. Kennedy, \& E. L. Piza (Eds.), Risk terrain modeling diagnostics utility user manual, Version 1.0. Newark, NJ: Rutgers Center on Public Security.

Hoyt, H. (1939). The structure and growth of residential neighborhoods in American cities. Washington, DC: Federal Housing Administration.

Irvin-Erickson, Y. (2014). Identifying risky places for crime: An analysis of the criminogenic spatiotemporal influences of landscape features on street robberies (Doctoral Dissertation). Newark, NJ: Rutgers University-Graduate School.

Kennedy, L. W. (1983). The urban kaleidoscope: Canadian perspectives. New York, NY: McGraw-Hill Ryerson Limited.

Kennedy, L. W., Caplan, J. M., \& Piza, E. L. (2011). Risk clusters, hotspots, and spatial intelligence: Risk terrain modeling as an algorithm for police resource allocation strategies. Journal of Quantitative Criminology, 27, 339-362.

Kennedy, L. W., Caplan, J. M., \& Piza, E. L. (2015). A multi-jurisdictional test of risk terrain modeling and place-based evaluation of environmental risk-based patrol deployment strategies. Newark, NJ: Rutgers Center on Public Security.

Kennedy, L. W., Caplan, J. M., Piza, E. L., \& Buccine-Schraeder. (2015). Vulnerability and exposure to crime: Applying risk terrain modeling to the study of assault in Chicago. Applied Spatial Analysis. http://dx.doi.org/10.1007/s12061-015-9165-z.

Koper, C. S., Taylor, B. G., \& Woods, D. J. (2013). A randomized test of initial and residual deterrence from directed patrols and use of license plate readers at crime hot spots. Journal of Experimental Criminology, 9(2), 213-244.

Lee, M. R. (2006). The religious institutional base and violent crime in rural areas. Journal for the Scientific Study of Religion, 45(3), 309-324.

Lynch, K. (1960). The image of the city. Cambridge, MA: The MIT Press.

Novak, K. J., Fox, A. M., Carr, C. M., \& Spade, D. A. (2016). The efficacy of foot patrol in violent places. Journal of Experimental Criminology, 12(3), 465-475.

Piza, E., Feng, S., Kennedy, L., \& Caplan, J. (2016). Place-based correlates of motor vehicle theft and recovery: Measuring spatial influence across neighborhood context. Urban Studies. http://dx.doi.org/10.1177/0042098016664299.

Piza, E. L., \& O'Hara, B. A. (2014). Saturation foot-patrol in a high-violence area: A quasi- experimental evaluation. Justice Quarterly, 31(4), 693-718.

Poon, L. (2015, September 11). Mapping the 'urban fingerprints' of cities. CityLab. Retrieved from: http://www.citylab.com/housing/2015/09/mapping-the-urbanfingerprints-of-cities/404923/.

Ratcliffe, J. H., Taniguchi, T., Groff, E. R., \& Wood, J. D. (2011). The philadelphia foot patrol experiment: A randomized controlled trial of police patrol effectiveness in violent crime hotspots. Criminology, 49(3), 795-831. 
Rengert, G. F., Ratcliffe, J. H., \& Chakravorty, S. (2005). Policing illegal drug markets: Geographic approaches to crime reduction. Monsey, NY: Criminal Justice Press.

Roncek, D. W., \& Bell, R. (1981). Bars, blocks, and crimes. Journal of Environmental Systems, 11(1), 35-47.

Roncek, D. W., \& Faggiani, D. (1985). High schools and crime: A replication. The Sociological Quarterly, 26, 491-505.

Roncek, D. W., \& Lobosco, A. (1983). The effect of high schools on crime in their neighborhoods. Social Science Quarterly, 64(3), 598-613.

Roncek, D. W. \& Maier, P. A. (1991). Bars, blocks, and crimes revisited: Linking the theory of routine activities to the empiricism of "hot spots." Criminology, 29, $725-753$

Rosenfeld, R., Deckard, M. J., \& Blackburn, E. (2014). The effects of directed patrol and self-initiated enforcement on firearm violence: A randomized controlled study of hot spot policing. Criminology, 52(3), 428-449.

Sampson, R. J., \& Groves, W. B. (1989). Community structure and crime: Testing social-disorganization theory. American Journal of Sociology, 94(9), 774-802.

Sampson, R. J., Morenoff, J. D., \& Gannon-Rowley, T. (2002). Assessing “neighbor hood effects": Social processes and new directions in research. Annual Review of Sociology, 28, 443-478.

Shaw, C. R., \& McKay, H. D. (1942). Juvenile delinquency in urban areas. Chicago, IL: University of Chicago Press.

Sherman, L. W. (1995). Hot spots of crime and criminal careers of places. In J. E. Eck \& D. Weisburd (Eds.), Crime and place (pp. 13-52). Monsey, NY: Criminal Justice Press.

Sherman, L. W., Gartin, P. R., \& Buerger, M. E. (1989). Hot spots of predatory crime: Routine activities and the criminology of place. Criminology, 27, 27-56.

Sherman, L. W., \& Weisburd, D. (1995). General deterrent effects of police patrol in crime "hot spots": A randomized, controlled trial. Justice Quarterly, 12(4), $625-648$

Skogan, W., \& Frydl, K. (2004). Fairness and effectiveness in policing: The evidence. Committee to Review Research on Police Policy and Practices. Committee on Law and Justice, Division of Behavioral and Social Sciences and Education. Washington, D.C: The National Academies Press.

Smith, W. R., Frazee, S. G., \& Davison, E. L. (2000). Furthering the integration of routine activity and social disorganization theories: Small units of analysis and the study of street robbery as a diffusion process. Criminology, 38, 489-524.

Spelman, W. (1993). Abandoned buildings: Magnets for crime? Journal of Criminal Justice, 21, 481-495.

St Jean, P. K. B. (2007). Pockets of crime: Broken windows, collective efficacy, and the criminal point of view. Chicago, IL: University of Chicago Press.

Weisburd, D. (2008). Place-based policing. Ideas in American policing. Washington, DC: Police Foundation.

Weisburd, D., Bernasco, W., \& Bruinsma, G. (2008). Putting crime in its place: Units of analysis in geographic criminology. New York, NY: Springer.

Weisburd, D., \& Green, L. (1995). Policing drug hot spots: The Jersey City drug market analysis experiment. Justice Quarterly, 12, 711-735.

Weisburd, D. L., Groff, E. R., \& Yang, S. M. (2012). The criminology of place: Street segments and our understanding of the crime problem. New York, NY: Oxford University Press.

Wortley, R., \& Mazerolle, L. (2008). Environmental criminology and crime analysis. New York, NY: Routledge.

Wright, R. T., \& Decker, S. H. (1997). Armed robbers in action: Stickups and street culture. Lebanon, NH: Northeastern University Press. 